J O U R N A O F French and Francophone Philosophy
RE V UE DE LA

philosophie française et de langue française

\title{
Passport for a Hoped Immortality
}

\section{Albert Memmi}

Journal of French and Francophone Philosophy - Revue de la philosophie française et de langue française, Vol XIX, No 2 (2011) pp 13-14

\author{
Vol XIX, No 2 (2011) \\ ISSN 1936-6280 (print) \\ ISSN 2155-1162 (online) \\ DOI $10.5195 /$ jffp. 2011.508 \\ www.jffp.org
}

\section{(c)) Br-NC-ND}

This work is licensed under a Creative Commons Attribution-Noncommercial-No Derivative Works 3.0 United States License.

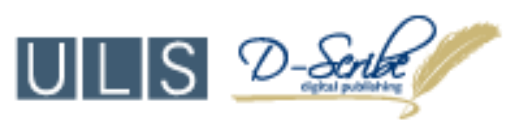

This journal is operated by the University Library System of the University of Pittsburgh as part of its D-Scribe Digital Publishing Program, and is co-sponsored by the University of Pittsburgh Press 


\section{Passport for a Hoped Immortality}

\section{Albert Memmi}

Mr. and Mrs. Bernheim, ladies and gentlemen, dear reader-friends, or friend-readers (because I wish that my readers become my friends and my friends become readers).

What could I add after such intelligent and generous words from Professor Annie Roselmann. I am proud to have been her Professor, as she revealed to you, and I am grateful to her, because having such students reassures me on my own itinerary.

In Tunis, on the alleyway of Tronja where I was born and spent my childhood, there were rituals that gave a rhythm to our common life (which we often shared with our Muslim fellow-citizens).

Here is one that I still remember.

On holidays, those who could afford it made a lot of cakes and sent full plates of them to their neighbors.

But this gift called for a return: our mother never let a plate go back empty: she always put at least a few treats (dragées) that were left over from a bar mitzvah or marriage.

By awarding me this prize, you have given me a delicious gift. So here, in return, are my treats (dragées): I'll tell you a secret.

I am at the age of settling accounts, where one looks back over the whole of one's life and asks oneself if one has lived it well: what were the mistakes, the successes, and the occasional regrets.

For the writer I have become, what have I contributed to the basket of the common culture? Why should I be concerned about posterity, when I am someone who does not believe that there is another world? Why so much stubborn effort to build a sort of passport for a hoped immortality?

And so, what little I have discovered I am giving to you in this groping response. One must live, act and think now, in this life, as if one were worthy of a hoped immortality. To be brief, find and communicate the truth, if 
possible. Beware of prejudice and utopias, of all dogmas, including those that are one's own. Live without submission and without compromise. For me, this is the ethics of the thinker and the foundation of what I mean by philosophy.

Then try to develop the proper form for communicating it: that is the role of the writer, which I have also tried to be.

Of course, there are other passports: it is up to each person to subscribe to his or her own. For thinkers and artists, the work is the passport of this hope.

By giving me this prize, you give me comfort; please accept my great appreciation for this.

(Acceptance speech delivered to the Bernheim Foundation of French Judaism, May 16, 2011) 